\title{
Amiodarone-induced blue-gray facial pigmentation - case report
}

\section{(D)Almin Handanagić ${ }^{*}$, (DEdin Begić ${ }^{2}$, Alma Handanagićc \\ 'Cantonal Hospital "Dr Irfan Ljubijankić", Bihać, Bosnia and Herzegovina \\ ${ }^{2}$ General Hospital «Prim. dr. Abdulah Nakaš», Sarajevo, Bosnia and Herzegovina}

RECEIVED:

December 6, 2020

ACCEPTED:

December 18, 2020

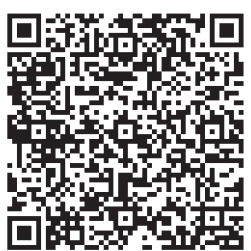

$\square$ Cardiologia Croatica 2021;16(1-2):66.
KEYWORDS: amiodarone, skin, therapy.

CITATION: Cardiol Croat. 2021;16(1-2):66. | https://doi.org/10.15836/ccar2021.66

*ADDRESS FOR CORRESPONDENCE: Almin Handanagić, Cantonal Hospital “Dr Irfan Ljubijankić”, Darivalaca krvi 67, 77000 Bihać, Bosnia and Herzegovina. / Phone: +387-60-3534516 / E-mail: almaalmin@hotmail.com

ORCID: Almin Handanagić, https://orcid.org/0000-0002-6421-3668 • Edin Begić, https://orcid.org/0000-0001-6842-262X

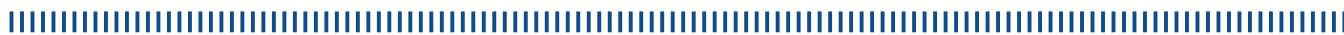

Case Report: A 73-year-old patient was hospitalized at the Department of Internal medicine, Cantonal Hospital Bihać, due to chest pain and dyspnea. He stated that he had a myocardial infarction 15 years ago. Coronarography verified triple-vessel coronary artery disease and he underwent surgical revascularization. Since then, he received antiaggregation therapy, angiotensin-converting enzyme (ACE) inhibitor, beta-blocker, amiodarone, nitroglycerin, diuretic and statin. By echocardiography, preserved systolic function was verified, along with hypokinesis of the mediobasal segment of the inferior and basal segment of the posterior wall. He pointed out that in the past 3-4 years he got an ashy color of his facial skin (Figure 1). Dermatologist suspected on phototoxic reaction of amiodarone and recommended to exclude amiodarone from therapy, along with the administration of antihistamines and local photoprotection with Sun Creme Sensitive Protect SPF 50+. After two months, the patient has undergone stress testing and new coronarography was indicated. In the control findings of a dermatovenerologist, the previously described changes on the facial skin were in regression.

Conclusion: The occurrence of facial pigmentation is associated with long-term use of amiodarone ${ }^{1}$, and in case of its occurrence, the consequences of the therapeutic modality should be taken into account.

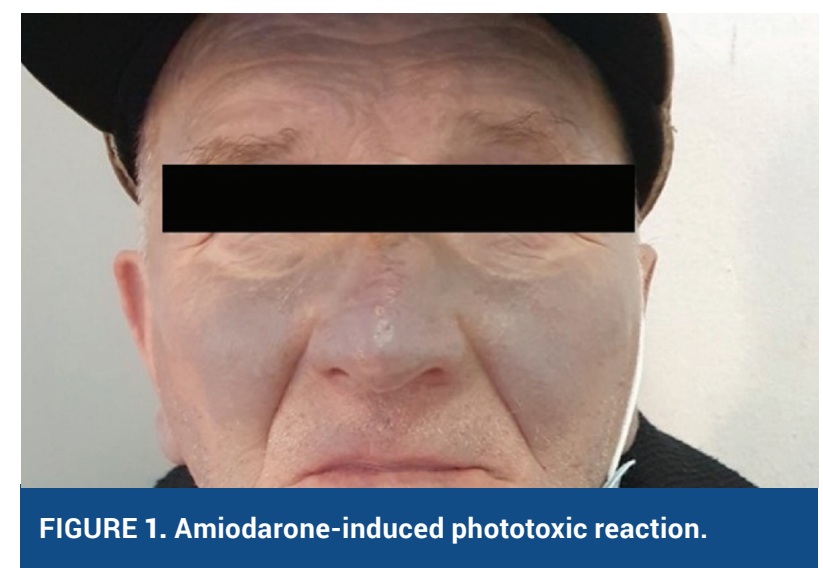

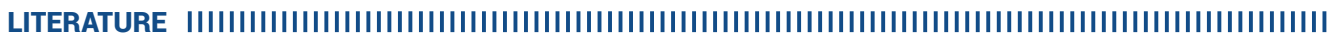
1. Jaworski K, Walecka I, Rudnicka L, Gnatowski M, Kosior DA. Cutaneous adverse reactions of amiodarone. Med Sci Monit. 2014 Nov 21;20:2369-72. https://doi.org/10.12659/MSM.890881 